УДК 616.831.7-005.4-076: 57.086

DOI: $10.21802 / 2304-7437-2019-5(57)-59-64$

\title{
NEW DEVELOPMENTS IN MORPHOLOGICAL DIAGNOSIS OF ISCHEMIC STROKE IN THE VERTEBRO-BASILAR BASIN
}

\author{
I. A. Hryhorova, O. L. Ibragimova, O. R. Eskin, \\ L. V. Tykhonova, N. N. Hryhorov
}

Kharkiv National Medical University; Neurology department № 1; Ukraine, Kharkiv, av.Nauki, 4, 61022; T. (057)70567 43; grygorova_i@ukr.net

Clinical manifestations of ischemic stroke in the VBB depend on many factors and their diagnosis is often difficult due to atypical clinical presentation and rare classic symptoms $[1 ; 2 ; 8]$. The pathomorphological comparison of changes in the brain in patients who died of ischemic vertebrobasilar and carotid stroke. In VBB stroke stenotic lesion precerebral and intracerebral vertebral artery segments are of most important etiopathogenetic importance. Maximum intensity of the pathological changes in ischemic stroke occurs at 2-3 days of onset of irreversible damage of structural elements of the nervous tissue in the area of the primary ischemic lesion.

Key words: ischemic stroke, pathomorphological comparison of changes, pathogenetic heterogeneity.

Problem statement and analysis of the latest research. In our country, strokes are the second leading cause of death and the leading cause of disability, creating a serious burden for the health system, the economy and society. Only $20 \%$ of patients survive alive after stroke, returning to an active way of life $[1 ; 5]$. The vast majority of acute disturbances of cerebral blood circulation (up to $90 \%$ in developed countries and nearly $80 \%$ in Ukraine) constitute ischemic stroke [9], of which up to $20 \%$ develop in vertebrobasilar basin (VBB) [2-4; 9].

By VBB includes in various functional and phylogenetic relation to parts of the brain, namely the cervical spinal cord, brain stem and cerebellum, the part of the thalamus and hypothalamus, occipital lobe, posterior and mediobasal temporal lobes $[3 ; 6]$. Clinical manifestations of ischemic stroke in the VBB depend on many factors and their diagnosis is often difficult due to atypical clinical presentation and rare classic symptoms $[1 ; 2 ; 8]$.

The purpose of our study is to provide pathomorphological comparison of changes in the brain in patients who died of ischemic vertebrobasilar and carotid stroke.

Materials and methods. The results of a post mortem examination of the cortex of the frontal, parietal, temporal and occipital lobes of the brain, hypothalamus, corpus callosum, thalamus, caudate nucleus cerebral peduncle, pons, medulla and cerebellum, as well as the heart and greater vessels.

ISSN 2304-7437. Прикарпатський вісник НТШ. Пульс. - 2019. - № 5(57). 
Assessment of pathologic changes in the main extra- and intracerebral arteries, myocardium, coronary arteries and heart valves, aorta, as well as changes in different parts of the brain helps to clarify the pathogenic variant of ischemic stroke (IS).

Results and discussion. The study showed that $5^{\text {th }}(17 \%)$ patients died during the first 3 days of onset, 20 (67\%) patients died in the period from 4 to 10 days and one patient died $20^{\text {th }}$ day of ischemic stroke.

The patients who died of ischemic stroke were predominantly at the age of $71-80$ years - $15(50 \%), 7(23 \%)$ were $61-70,4(13,3 \%)$ patients were over 80 . The patients who died at the age of $51-70$ were predominated males $(73 \%)$. The patients who died were predominated at the age of 71 female 13 $(68 \%)$ cases.

Autopsy showed impairments in the basin of the left anterior cerebral artery - $2(7 \%)$ cases, the right middle cerebral artery $-12(40 \%)$, the left middle cerebral artery - $13(43 \%)$, the right posterior cerebral artery - $6(20 \%)$, the upper right cerebellar artery $-3(10 \%)$ and the posterior-inferior cerebellar artery $2(7 \%)$ cases. Simultaneous impairment of basins of the left and right middle cerebral artery observed in $5(17 \%)$ cases. The most frequent localization of the impairment in our study was the hemispheres of the brain. In $4(13 \%)$ cases the focus center was located in the trunk, in $3(10 \%)$ - in the cerebellum, $2(7 \%)$ in the region of the pons, $2(7 \%)$ in the thalamus and 4 $(13 \%)$ in the subcortical nuclei. In $7(23 \%)$ cases there was a simultaneous development of the two or more foci.

Extensive (IS), spreading to all areas of the brain that receive blood from the middle and anterior cerebral arteries was observed in $5(17 \%)$ cases. $21(70 \%)$ of the deceased were found to have infarctions and $4(13 \%)$ moderate. Large and moderate ischemic strokes were more often multiple - from 2 to 3 foci. "White" ischemic infarctions were found in 19 (63\%) of deceased infarctions with hemorrhagic transformation in 11 (37\%) deceased.

Atherothrombotic ischemic stroke was diagnosed in $15(50 \%)$ deceased secondary to complicated atherosclerosis of precerebral arteries and combined complications of atherosclerosis of precerebral and cerebral arteries. Precerebral artery (internal carotid, vertebral, large and middle cerebral arteries were affected by atheromatous eccentric plaques, mainly in the area of their proximal area and in places of their branching, tortuosity, fusion. Constriction of vascular lumen ranged from 25 to $75 \%$. Stenotic plaques in the carotid arteries, were usually accompanied by advanced atherosclerosis of arteries of vertebrobasilar system. Cerebral arteries in $87 \%$ of cases were affected in the area of circle of Willis, and arteriosclerosis of cerebral arteries was of occlusive nature, reducing the lumen of artery to $75 \%$. In all cases of stem localization of IS we determined atherosclerotic impairment of distal segments of the vertebral arteries, more often in the area of formation of the basilar artery. The degree of narrowing of the vertebral arteries ranged from 50 to $80 \%$. Such combined atherostenosis led to a sharp decrease in the ca-

ISSN 2304-7437. Прикарпатський вісник НТШ. Пульс. - 2019. - № 5(57). 
pacity of collateral circulation in the arterial circulation of the brain, contributing to an increase in the severity and number of ischemic foci. This variant of stroke as often accompanied by hemorrhagic component.

Atheromatous plaques were complicated by the development of atherothrombosis. Such plaques we found damaged endothelial cover or deep ulceration was which is superimposed on a thrombotic mass, resulting in complete closure of the lumen of the vessel or to its critical narrowing. Multiple lacunar infarctions in the course of small intracerebral arteries in atherothrombotic stroke could be the consequence of transient ischemic attacks.

Embolic IS was detected in $13(43 \%)$ patients and was observed in a full or partial occlusion of cerebral artery by an embolus. Most often, this pathogenic variant was observed in the area of blood supply of the middle cerebral artery. The size of focus was usually medium or large and in such cases it often involved hemorrhagic component. Morphological features of cardioembolic stroke were the presence of aortic thromboembolus or heart valve leaflets. Thromboembolism had no connection with de-endothelialized artery wall, so in the time course we observed only homogenization, compaction of thromboembolic mass and presence of hemosiderin. Thromboembolism was not typically accompanied by the presence of endothelial cells, fibroblasts, macrophages in the thickness of thromboembolus as well as coating of thromboembolus by endothelial cells at later stages. Aortic thromboembolism origin occurred in $9(30 \%)$ cases. Cardiogenic embolism in valvular lesions detected in $4(13 \%)$ cases. $3(10 \%)$ patients with cardiogenic emboli had concomitant aortic thromboembolism. It should be noted that the signs of ischemic stroke were identified in $7(23 \%)$ deceased, contracture changes in $11(37 \%)$, macrofocal (postinfarction) cardiosclerosis in $4(13 \%)$, small foci cardiosclerosis in $26(87 \%)$. All cases were found have signs of myocardial hypertrophy.

Hemodynamic ischemic stroke was identified in $2(7 \%)$ cases in vertebrobasilar localization of stroke and was due to cerebral hypoperfusion with the development of ischemia of cerebrovascular insufficiency type. This option developed secondary to atherosclerotic stenosis of the arteries of extraand intracranial arteries in the area adjacent to the blood supply. Morphological signs of hemodynamic mechanism of IS were free lumen of the corresponding cerebral artery, except for the presence of atherosclerotic plaques, absence of paresis of the arterial wall, smooth shiny endocardium without intact parietal thrombi, lack thereof in the initial part of the aorta. These attributes were relative, not absolute, because successful treatment, can generally liberate the lumen from thrombotic masses.

Patients with ischemic stroke in the VBB also underwent measurement of chronic vertebrobasilar insufficiency in the form of lacunar infarctions of various term-strokes of microcirculation associated with impairment of perforating arteries. They were found revealed signs of neuronal cell death and

ISSN 2304-7437. Прикарпатський вісник НТШ. Пульс. - 2019. - № 5(57). 
proliferation of glial cells, were further defined atrophic changes of the cerebral cortex. Such changes were identified in six (20\%) autopsy cases. None of these cases were found to have hemorrhagic transformation.

Comparison of pathological changes in different periods showed that the maximum changes occurred on the $2^{\text {nd }}-3^{\text {rd }}$ days of onset. During this period from unaffected tissues clearly demarcated focus of full liquefactive necrosis, which occured within the death of all the structural elements of the nervous tissue, such as cells and nerve fibers, glia, blood vessels. Also there was ischemic neuronal damage, cytolysis, loss of neurons in preservance of other structural elements of brain substance, tigrolysis (chromatolysis) and hyperchromatosis in remaining neurons, disintegration of myelin nerve fibers in the white matter. Tigrolysis was accompanied by other cell changes, namely swelling and displacement of nucleus to the periphery, the appearance of lipofuscin in the cytoplasm or vacuole, cell shrinkage and atrophy.

Perifocal zone surrounding the area IS was constantly found to have of dyshemic signs disorders: signs of the venous stasis and spasm of arterioles, accompanied by a decrease in their lumen and decreased blood supply to the cerebral structures, plasmatic impregnation of their walls, perivascular edema, single small hemorrhages and focal changes of brain tissue in the form of edema, degenerative changes of neurons. Around unaffected areas there was marked perivascular and pericellular edema brain substance that contribute to the deterioration of cerebral hemodynamics and led to an increase in the level of ischemic brain damage, whereby to the $2^{\text {nd }}-3^{\text {rd }}$ days brain substance acquired perforated (honeycomb) character.

Thus, pathomorphological changes in the deceased at different times after the ischemic stroke were consistent with the concept of pathogenetic heterogeneity of ischemic strokes, and the time course of their development demonstrates the need for the earliest pathogenetic based treatment aimed at preventing progression of perifocal injury and brain edema.

Findings. IS is characterized by a wide variety of macroscopic and microscopic changes due to etiology and pathogenesis, localization of lesions and disease duration. Extensive and large ischemic cerebral infarction are pathogenically associated with occlusive atherothrombosis of one or more arterial branches, cardiothromboembolism or arterio-arterial thromboembolism, moderate ones occurred more frequently by hemodynamic mechanism and lacunar infarctions development was associated with lesions of perforating arteries of the brain. The magnitude and location of ischemic infarction were influenced by localization and severity of hemodynamically significant atherostenosis or atherothrombosis, the rate of development of stenosis or occlusion of blood vessels and as a result, cerebral ischemia, development of collateral circulation. In VBB stroke stenotic lesion precerebral and intracerebral vertebral artery segments are of most important etiopathogenetic importance. Maximum intensity of the pathological changes in ischemic stroke occurs at 2-3 days of onset of irreversible damage of structural ele-

ISSN 2304-7437. Прикарпатський вісник НТШ. Пульс. - 2019. - № 5(57). 
ments of the nervous tissue in the area of the primary ischemic lesion with the presence of perifocal zone, characterized by marred of perivascular and pericellular edema and reduction of microvasculare race.

Prospects for further research in this direction. The timely and correct diagnosis depends on the choice of treatment strategy, which determines the outcome of the disease. In this connection it is important to further improving the early diagnosis of ischemic strokes to optimize the treatment strategy in the acute period of the disease.

\section{References}

1. Vinnichuk S.M. Cerebrovascular diseases. Naukova dumka. 2009; 250.

2. Vorlou G.P, Dennis M., J. Gane, etc. Stroke:. A practical guide for the management of patients. Politehnika. 2015; 630.

3. Gusev E.I, Skvortsov E.I., Chekneva N.S. et al. Treatment of acute stroke (diagnostic and therapeutic algorithms). 2014; 240.

4. Gusev E.I. Research methods in neurology and neurosurgery. Guide for doctors. 2015; 250.

5. Selihova M.V. Diagnosis and treatment of motor disorders in patients in the early recovery period of ischemic stroke. Abstract. Dis. cand. honey. nauk. 2015; 40.

6. Fidler S.M. Clinico-neurophysiological study of the functional state of the brain in acute hemispheric ischemic stroke. Abstract. Dis. cand. honey. nauk. 2011;26.

7. Moskalenko Y., Beketov A.I., Orlov R.S. Cerebral circulation. Nauka. $2012 ; 160$.

8. Gafurov B.G. Hemispheric relations and non-specific system of the brain in cerebral stroke. Abstract. Dis. Drs. honey. nauk. 2012;126.

9. Vereshchagin N.M., Morgunov V.A., Gulevskaya T.S. Brain pathology of atherosclerosis and arterial hypertension. Meditsina. 2007; 208.

Стаття надійила до редакиійної колегії 23.02.2019 p. Рекомендовано до друку д.м.н., професором Синоверською О.Б., д.м.н., професором Прищуком Л.А. (м. Київ)

\section{НОВІ РОЗРОБКИ В МОРФОЛОГІЧНІЙ ДІАГНОСТИЦІ ІШЕМІЧНОГО ІНСУЛЬТУ У ВЕРТЕБРО-БАЗИЛЯРНОМУ БАСЕЙНІ}

\section{І. А. Григорова, О. Л. Ібрагімова, О. Р. Ескін, Л. В.Тихонова, Н. Н. Григоров}

Харківський національний медичний університет; кафедра неврології № 1; Украӥна, просп. Науки, 4, 61022; T. (057) 70567 43; grygorova_i@ukr.net 
Клінічні прояви ішемічного інсульту у ВББ залежать від багатьох факторі, $і$ їх діагностика часто буває складною через атипові клінічні прояви $і$ рідкісні класичні симптоми. Патоморфологічно порівняння змін мозку у паиієнтів, які померли від ішемічного вертебробазилярного i каротидного інсульту. При інсульті у ВББ найважливіше етіопатогенетичне значення мають стенозування прецеребрального $і$ внутрішньомозкового сегментів хребетної артерій. Максимальна інтенсивність патологічних змін при ішемічному інсульті відбувається на 2-3 добу від початку незворотного пошкодження структурних елементів нервової тканини в ділянці первинного ішемічного ураження.

Ключові слова: ішемічний інсульт, патоморфологічне порівняння змін, патогенетична гетерогенність. 